\title{
Sustainable Washing for Denim Garments by Enzymatic Treatment
}

\author{
Md. Mashiur Rahman Khan and Md. Ibrahim H. Mondal ${ }^{*}$ \\ Polymer and Textile Research Lab., Department of Applied Chemistry \& Chemical Engineering, University of \\ Rajshahi, Bangladesh. \\ Md. Zulhash Uddin \\ Department of Wet Processing Engineering, Bangladesh University of Textiles, Tejgaon, Dhaka-1208, \\ Bangladesh
}

\begin{abstract}
Denim garment is the most preferred of today's youth. This paper presents the effect of enzyme wash using cellulase enzyme on the properties of denim garments to develop novel design and fashion. Three parameters in enzyme washing namely concentration of enzyme, washing temperature and time at pH 5.5 were considered. To investigate the optimum washing condition, indigo dyed cotton denim garments (trousers) were chosen and processed by enzyme with the concentration of $0.5 \%$ to $3.5 \%$, temperature $40^{\circ} \mathrm{C}$ to $70^{\circ} \mathrm{C}$ and time $20 \mathrm{~min}$ to $60 \mathrm{~min}$ for the achievement with desired worn and aged effect. The effect of each parameter is discussed, and denim garment's properties like tensile strength, elongation at break, weight loss, stiffness, water absorption, shrinkage, color fading and morphological values by SEM were evaluated. The optimized washing condition for the best value is $2 \%$ enzyme concentration at $55^{\circ} \mathrm{C}$ for 40 min.
\end{abstract}

Keywords: denim garment, cellulase enzyme, tensile strength, sustainability

\section{Introduction}

Eco-friendly sustainable garment design is the new challenge for garment designers and producers, because the consumers are concerned in eco-fashion in the last decade. In the fast changing fashion trends, all are now motivated to practice sustainability in design and production processes. Denim is very strong, stiff and hard wearing fabric. Denim garment (Jeans) washing is known as one of the widely used finishing treatment that has vast usage in textile sectors because of creating special appearance and making fashionable and wear comfortable garments of the present day world and commonly used. Without finishing treatments, denim garment is uncomfortable to wear, due to its weaving and dyeing effects. For this it essentially needs a finishing treatment to make it softer, smooth and comfortable to wear performance. Popularity of garments was specially on denim garments in the World market have been increasing day by day ${ }^{3}$. To meet up the quick change of current demands of customers, technologists are trying to introduce new designs and fashion on denim garments by using different washing methods. The most commonly denim washing methods are enzyme wash, bleach wash, acid wash, normal wash, stone wash, etc. Among the washing methods, enzymatic method is widely used method in industry ${ }^{4,5}$. However, enzyme treatment of cellulosic garments degrades cellulose at the ends or in the middle of the cellulose chains, yielding shorter chain cellulose polymers, and reduces its mechanical strength ${ }^{6}$. But cellulase treatments have been successful at improving fiber flexibility, desirable appearance and soft handle of cotton denim garments ${ }^{7}$. So, enzyme washing using cellulase is chosen for this work.
In this study, a sustainable and environment friendly process have explored for denim washing with cellulase enzyme that developed new design and fashion and is produced denim garments as a value-added product with high wear performance to satisfy customer's need. In addition, the effects of various wash parameters using cellulase enzyme on the properties of denim garments have investigated and characterized.

\section{Materials \& Methods}

\subsection{Materials}

Denim fabric was collected from Beximco Textile Mills Ltd., Dhaka, Bangladesh and garments (trousers) were manufactured in the sewing lab. These comprised 100\% cotton fabric (GSM 318), twill, weave 3/1, construction $70 \times 42 / 10 \times 9$, indigo dyed fabric. Garments were enzyme washed using the standard recipe ${ }^{8}$. Genzyme SL, (cellulase enzyme, Sri Lanka); detergent (Kohinoor, BD); Bio.D. (Biological detergent as desizing agent, Germany); soda ash (China), acetic acid (China) and textsoft softener (Germany) were purchased.

\subsection{Methods}

\subsubsection{Desizing Treatment}

Denim trousers were desized using detergent, desizing agent and soda ash. This treatment was conducted in liquor containing soda ash (1.2 g/l), detergent (0.6 g/l), and desizing agent $(0.6 \mathrm{~g} / \mathrm{l})$ and material to liquor ratio of 1:30 in a laboratory scale sample washing machine at $60^{\circ} \mathrm{C}$ for $20 \mathrm{~min}$. The garments were then washed with hot water $\left(70^{\circ} \mathrm{C}\right)$ followed by cold water wash.

*Corresponding Author: Md. Ibrahim H. Mondal

Email: mihmondal@yahoo.com 
Table 1: Effect of enzyme concentration on the characteristics (physical and mechanical properties) of treated denim garments

\begin{tabular}{|c|c|c|c|c|c|c|c|c|c|c|c|}
\hline \multirow[t]{2}{*}{$\begin{array}{c}\text { Conc. of } \\
\text { cellulase } \\
\text { enzyme } \\
\%\end{array}$} & \multicolumn{2}{|c|}{$\begin{array}{c}\text { Tensile } \\
\text { strength } \\
\text { (Kg f) }\end{array}$} & \multirow{2}{*}{$\begin{array}{c}\text { Dimen- } \\
\text { sional } \\
\text { stability } \\
\text { (shrink) } \\
\% \\
\end{array}$} & \multirow[t]{2}{*}{$\begin{array}{c}\text { Weight } \\
\text { of } \\
\text { fabric } \\
\text { (GSM) }\end{array}$} & \multirow[t]{2}{*}{$\begin{array}{c}\text { Stiff- } \\
\text { ness } \\
(\mathrm{cm})\end{array}$} & \multirow[t]{2}{*}{$\begin{array}{c}\text { Water } \\
\text { absor- } \\
\text { ption } \\
\text { (\%) }\end{array}$} & \multirow[t]{2}{*}{$\begin{array}{c}\text { Moistur } \\
\text { e } \\
\text { content } \\
(\%)\end{array}$} & \multirow[t]{2}{*}{$\begin{array}{l}\text { Moisture } \\
\text { regain } \\
(\%)\end{array}$} & \multirow[t]{2}{*}{$\begin{array}{c}\text { EPI } \\
\& \\
\text { PPI }\end{array}$} & \multirow{2}{*}{$\begin{array}{c}\text { Elong- } \\
\text { ation } \\
\text { at } \\
\text { break } \\
(\%) \\
\end{array}$} & \multirow[t]{2}{*}{$\begin{array}{c}\text { Color } \\
\text { shade } \\
\text { (rati- } \\
\text { ng) }\end{array}$} \\
\hline & Warp & Weft & & & & & & & & & \\
\hline $\begin{array}{c}0.0 \\
\text { Before } \\
\text { wash }\end{array}$ & $245(0)$ & $\begin{array}{l}136 \\
(0)\end{array}$ & 0 & $\begin{array}{l}318 \\
(0)\end{array}$ & $\begin{array}{l}4.5 \\
(0)\end{array}$ & 126 & 7.40 & 7.53 & $\begin{array}{c}70 \\
\times 42\end{array}$ & $\begin{array}{c}\mathrm{L}=21 \\
\mathrm{~W}=16\end{array}$ & 5 \\
\hline 0.5 & $\begin{array}{l}230 \\
(-6 \%)\end{array}$ & $\begin{array}{c}124 \\
(9 \%)\end{array}$ & $\begin{array}{c}\mathrm{L}=-4.75 \\
\mathrm{~W}=0\end{array}$ & $\begin{array}{c}326 \\
(+2.5 \\
\%) \\
\end{array}$ & $\begin{array}{c}3.2 \\
(-28 \\
\%) \\
\end{array}$ & 145 & 8.81 & 7.95 & $\begin{array}{c}70 \\
\times 46\end{array}$ & $\begin{array}{l}\mathrm{L}=36 \\
\mathrm{~W}=20\end{array}$ & $4 / 5$ \\
\hline 1.0 & $\begin{array}{l}220 \\
(-10 \%)\end{array}$ & $\begin{array}{c}120 \\
(- \\
12 \%)\end{array}$ & $\begin{array}{r}\mathrm{L}=-5.6 \\
\mathrm{~W}=+0.5\end{array}$ & $\begin{array}{c}328 \\
(+3.0 \\
\%) \\
\end{array}$ & $\begin{array}{c}3.1 \\
(-31 \\
\%) \\
\end{array}$ & 150 & 8.90 & 8.20 & $\begin{array}{c}70 \\
\times 46\end{array}$ & $\begin{array}{c}\mathrm{L}=37 \\
\mathrm{~W}=22\end{array}$ & 4 \\
\hline 2.0 & $\begin{array}{l}205 \\
(-16 \%)\end{array}$ & $\begin{array}{c}106 \\
(-22 \\
\%) \\
\end{array}$ & $\begin{array}{c}\mathrm{L}=-6.4 \\
\mathrm{~W}=+0.5\end{array}$ & $\begin{array}{c}334 \\
(+5.0 \\
\%) \\
\end{array}$ & $\begin{array}{c}2.62 \\
(-42 \\
\%) \\
\end{array}$ & 155 & 8.92 & 8.60 & $\begin{array}{c}69 \\
\times 46\end{array}$ & $\begin{array}{c}\mathrm{L}=37 \\
\mathrm{~W}=22\end{array}$ & $3 / 4$ \\
\hline 3.0 & $\begin{array}{l}190 \\
(-22 \%)\end{array}$ & $\begin{array}{c}97 \\
(-29 \\
\%) \\
\end{array}$ & $\begin{array}{c}\mathrm{L}=-6.3 \\
\mathrm{~W}=+1.0\end{array}$ & $\begin{array}{c}334 \\
(+5.0 \\
\%) \\
\end{array}$ & $\begin{array}{c}2.49 \\
(-45 \\
\%) \\
\end{array}$ & 156 & 8.93 & 8.60 & $\begin{array}{c}69 \\
\times 46\end{array}$ & $\begin{array}{c}\mathrm{L}=34 \\
\mathrm{~W}=20\end{array}$ & 3 \\
\hline 3.5 & $\begin{array}{l}190 \\
(-22 \%)\end{array}$ & $\begin{array}{c}91 \\
(-33 \\
\%) \\
\end{array}$ & $\begin{array}{c}\mathrm{L}=-6.3 \\
\mathrm{~W}=+1.0\end{array}$ & $\begin{array}{c}330 \\
(+3.7 \%)\end{array}$ & $\begin{array}{c}2.49 \\
(-45 \%)\end{array}$ & 156 & 8.93 & 8.60 & $\begin{array}{c}69 \\
\times 46\end{array}$ & $\begin{array}{c}\mathrm{L}=34 \\
\mathrm{~W}=20\end{array}$ & 3 \\
\hline
\end{tabular}

A value at 0.0 concentrations represents the denim garments without cellulase enzyme treatment. Conditions used for enzyme washing treatment: cellulase enzyme, 0.5-3.5\%; acetic acid, $1 \mathrm{~g} / \mathrm{l}$; temperature, $55^{\circ} \mathrm{C}$; time, $40 \mathrm{~min} ; \mathrm{pH}, 5.5$; M: L ratio, 1:30.

\subsubsection{Enzyme (Cellulase) Treatment}

Desized trousers were treated using cellulase enzyme. This process was conducted in liquor containing acetic acid $(1 \mathrm{~g} / \mathrm{l})$ at $\mathrm{pH} 5.5$ and material to liquor ratio of 1:30. The enzyme treatment was carried out at different concentrations of Genzyme SL (0.5 - 3.5\%), temperatures $\left(40-70^{\circ} \mathrm{C}\right)$ and treatment time $(20-60$ min). After desired time the temperature was raised to $90^{\circ} \mathrm{C}$ for 1 min to stop enzyme action. The denim garments were then washed with hot water then washed with cold water. Finally, garments were softened with Textsoft softener $(1 \mathrm{~g} / \mathrm{l})$ at $40^{\circ} \mathrm{C}$ for $10 \mathrm{~min}$.

\subsection{Hydro-Extracting and Drying Processes}

After treatment, the washed denim trousers were squeezed in a laboratory scale hydro-extractor machine (Zanussi, Roaches, England) at $200 \mathrm{rpm}$ for 3-4 min to remove excess water and then dried in a steam drier (Opti-Dry, Roaches, England) at $75^{\circ} \mathrm{C}$ for $35-40 \mathrm{~min}$. Treated denim garments were then evaluated in testing machines and characterized of their physical and mechanical properties to determine product performance.

\subsection{Testing and Analysis}

Treated all denim trousers were conditioned at 65\% RH and at $20^{\circ} \mathrm{C}$ for $24 \mathrm{~h}$ before testing according to BS EN ISO 139:2005 and ASTM D1776.
- Moisture regains and moisture content (\%) was calculated from the difference in total fabric weight and oven dry weight according to BS 4784-2:1998 and ASTM D 1909.

- Tensile strength and elongation at break was determined by the US Standard Grab test method according to ASTM D 5034 and ASTM D 1682.

- Dimensional changes (shrinkage \%) was calculated from the difference in fabric length before and after washed garment according to AATCC test methods 96-2009,135-2010 and 150-2010 ; ASTM D 2724, BS 4931.

- Weight loss (\%) in fabric was calculated from the difference in fabric weight (GSM) before and after the treatment according to ASTM D 3776.

- Change in the original color shade of the fabric was rated using gray scale for color change according to AATCC test method 61.

- $\quad$ Stiffness was measured from the bending stiffness in fabric by Shirley stiffness tester according to BS 3356-1990.

- Water absorption was measured in fabric from the differences in rate of uptake according to BS 34491990.

- SEM was studied using a scanning electron microscopy (Hitachi, model-S 3400 N, Japan). 
Table 2: Effect of temperature on the physical and mechanical properties of treated denim garments

\begin{tabular}{|c|c|c|c|c|c|c|c|c|c|c|c|}
\hline \multirow{2}{*}{$\begin{array}{c}\text { Temp } \\
\left({ }^{\circ} \mathrm{C}\right)\end{array}$} & \multicolumn{2}{|c|}{$\begin{array}{c}\text { Tensile strength } \\
\text { (Kg f) }\end{array}$} & \multirow{2}{*}{$\begin{array}{c}\text { Dimen } \\
\text {-sional } \\
\text { stabilit } \\
\text { y } \\
\text { (shrink } \\
\text { ) } \\
\%)\end{array}$} & \multirow{2}{*}{$\begin{array}{c}\text { Weight } \\
\text { of } \\
\text { fabric } \\
\text { (GSM) }\end{array}$} & \multirow{2}{*}{$\begin{array}{l}\text { Stiff- } \\
\text { ness } \\
(\mathrm{cm})\end{array}$} & \multirow{2}{*}{$\begin{array}{c}\text { Water } \\
\text { Abso- } \\
\text { rption } \\
(\%)\end{array}$} & \multirow{2}{*}{$\begin{array}{c}\text { Moisture } \\
\text { content } \\
(\%)\end{array}$} & \multirow{2}{*}{$\begin{array}{c}\text { Moistur } \\
\text { e regain } \\
(\%)\end{array}$} & \multirow{2}{*}{$\begin{array}{c}\text { EPI } \\
\& \\
\text { PPI }\end{array}$} & \multirow{2}{*}{$\begin{array}{c}\text { Elongat- } \\
\text { ion at } \\
\text { break } \\
(\%)\end{array}$} & \multirow{2}{*}{$\begin{array}{c}\text { Color } \\
\text { shade } \\
\text { (rating) }\end{array}$} \\
\hline & Warp & Weft & & & & & & & & & \\
\hline $\begin{array}{c}0.0 \\
\text { Befor } \\
\text { e } \\
\text { wash }\end{array}$ & $245(0)$ & $136(0)$ & $0(0)$ & $318(0)$ & $4.5(0)$ & 126 & 7.4 & 7.53 & $\begin{array}{l}70 \\
\times 42\end{array}$ & $\begin{array}{c}\mathrm{L}=21 \\
\mathrm{~W}=16\end{array}$ & 5 \\
\hline 40 & $\begin{array}{c}223 \\
(-9 \%)\end{array}$ & $\begin{array}{c}118 \\
(-13 \%)\end{array}$ & $\begin{array}{r}\mathrm{L}=-6.0 \\
W=0\end{array}$ & $\begin{array}{c}330 \\
(+3.8 \%)\end{array}$ & $\begin{array}{c}3.0 \\
(- \\
33 \%)\end{array}$ & 145 & 8.81 & 7.95 & $\begin{array}{l}70 \\
\times 46\end{array}$ & $\begin{aligned} L & =36 \\
W & =20\end{aligned}$ & $4 / 5$ \\
\hline 50 & $\begin{array}{c}213 \\
(-13 \%)\end{array}$ & $\begin{array}{c}110 \\
(-19 \%)\end{array}$ & $\begin{array}{r}\mathrm{L}=-6.2 \\
W=0\end{array}$ & $\begin{array}{c}334 \\
(+5.0 \%)\end{array}$ & $\begin{array}{c}2.78 \\
(- \\
38 \%) \\
\end{array}$ & 150 & 8.90 & 8.20 & $\begin{array}{l}70 \\
x 46\end{array}$ & $\begin{aligned} L & =37 \\
W & =22\end{aligned}$ & 4 \\
\hline 55 & $\begin{array}{c}205 \\
(-16 \%)\end{array}$ & $\begin{array}{c}106 \\
(-22 \%)\end{array}$ & $\begin{array}{l}\mathrm{L}=-6.4 \\
W=+ \\
0.5\end{array}$ & $\begin{array}{c}334 \\
(+5.0 \%)\end{array}$ & $\begin{array}{c}2.62 \\
(- \\
42 \%) \\
\end{array}$ & 155 & 8.92 & 8.60 & $\begin{array}{l}69 \\
\times 46\end{array}$ & $\begin{array}{l}\mathrm{L}=37 \\
\mathrm{~W}=22\end{array}$ & $3 / 4$ \\
\hline 60 & $\begin{array}{c}193 \\
(-21 \%)\end{array}$ & $\begin{array}{c}95 \\
(-30 \%)\end{array}$ & $\begin{array}{c}\mathrm{L}=-6.6 \\
\mathrm{~W}= \\
+1.0\end{array}$ & $\begin{array}{c}334 \\
(+5.0 \%)\end{array}$ & $\begin{array}{c}2.50 \\
(- \\
44.4 \% \\
)\end{array}$ & 158 & 8.94 & 8.60 & $\begin{array}{l}69 \\
\times 46\end{array}$ & $\begin{aligned} \mathrm{L} & =33 \\
\mathrm{~W} & =24\end{aligned}$ & 3 \\
\hline 65 & $\begin{array}{c}190 \\
(-22 \%)\end{array}$ & $\begin{array}{c}95 \\
(-30 \%)\end{array}$ & $\begin{array}{c}\mathrm{L}=-7.2 \\
\mathrm{~W}= \\
+1.0\end{array}$ & $\begin{array}{c}333 \\
(+4.7 \%)\end{array}$ & $\begin{array}{c}2.47 \\
(- \\
45 \%)\end{array}$ & 158 & 8.93 & 8.60 & $\begin{array}{l}69 \\
\times 46\end{array}$ & $\begin{array}{c}\mathrm{L}=33 \\
\mathrm{~W}=24\end{array}$ & 3 \\
\hline 70 & $\begin{array}{c}190 \\
(-22 \%)\end{array}$ & $\begin{array}{c}95 \\
(-30 \%)\end{array}$ & $\begin{array}{c}\mathrm{L}=-7.2 \\
\mathrm{~W}= \\
+1.0\end{array}$ & $\begin{array}{c}332 \\
(+4.4 \%)\end{array}$ & $\begin{array}{c}2.47 \\
(- \\
45 \%) \\
\end{array}$ & 158 & 8.95 & 8.60 & $\begin{array}{l}69 \\
\times 46\end{array}$ & $\begin{array}{l}L=33 \\
W=24\end{array}$ & 3 \\
\hline
\end{tabular}

Conditions used: cellulase, 2\%; acetic acid, 1g/l; temp., $40-70^{\circ} \mathrm{C}$; time, $40 \mathrm{~min}$; pH, 5.5; M: L ratio, 1:30.

\section{Results \& Discussion}

\subsection{Concentration of Cellulase Enzyme}

Indigo dyed 100\% cotton denim garments (trousers) were chemically processed through desizing using Bio.D., soda ash and detergent. Then desized denim garments were processing using cellulase enzyme. The physical and mechanical properties of enzyme treated denim trousers with different concentrations were examined. Results obtained are summarized in Table 1.

It can be seen from Table 1 that, $0.5 \%$ concentration cause significant decrease of tensile strength and this decrease was higher at higher enzyme concentrations. It is observed that $3.5 \%$ concentration exhibited the highest decrease in the loss of tensile strength. It is assumed that cellulase enzyme degraded cotton under the conditions used. Cellulase enzyme first attacked on projecting fibers (micro-fibrils) having fabric surface, then attacked on yarn portion, hydrolyzed them slowly. After that it attacked on secondary wall. As a result, cotton fiber loosened and broken down quicker with the frictional forces of rotating cylinder of the washing machine. Denim hydrolysis by measuring the color fading from denim garments was monitored. The results disclose that increasing the enzyme concentration from 3.0 to $3.5 \%$ has no effect on color shade change, and $2 \%$ concentration is the optimum result for color fading.

Denim hydrolysis by measuring the stiffness from denim garments was also monitored. As evident, the stiffness of the denim garment decreased at $0.5 \%$ concentration significantly, and the decrease was more pronounced at higher enzyme concentration up to $3.0 \%$. After treatment with cellulase enzyme, the sizes (starch) of warp yarns were removed. As a result bending length was less and softness was increased. The increase was more pronounced at higher enzyme concentration up to $2 \%$ and softness was $42 \%$. The same holds true for the water absorption also. 
Table 3: Effect of time on the physical and mechanical properties of treated denim garments

\begin{tabular}{|c|c|c|c|c|c|c|c|c|c|c|c|}
\hline \multirow[t]{2}{*}{$\begin{array}{l}\text { Time } \\
\text { (min) }\end{array}$} & \multicolumn{2}{|c|}{$\begin{array}{c}\text { Tensile } \\
\text { strength } \\
\text { (Kg f) }\end{array}$} & \multirow{2}{*}{$\begin{array}{c}\text { Dimension } \\
\text { stability } \\
\text { (shrinks) } \\
\%\end{array}$} & \multirow{2}{*}{$\begin{array}{c}\text { Weight } \\
\text { of } \\
\text { fabric } \\
\text { (GSM) }\end{array}$} & \multirow[t]{2}{*}{$\begin{array}{l}\text { Stiff- } \\
\text { ness } \\
(\mathrm{cm})\end{array}$} & \multirow{2}{*}{$\begin{array}{l}\text { Water } \\
\text { absor } \\
\text { b } \\
(\%)\end{array}$} & \multirow[t]{2}{*}{$\begin{array}{l}\text { Moisture } \\
\text { content } \\
(\%)\end{array}$} & \multirow{2}{*}{$\begin{array}{l}\text { Moistu- } \\
\text { re } \\
\text { regain } \\
(\%)\end{array}$} & \multirow[t]{2}{*}{$\begin{array}{l}\text { EPI } \\
\& \\
\text { PPI }\end{array}$} & \multirow{2}{*}{$\begin{array}{l}\text { Elong- } \\
\text { ation at } \\
\text { break } \\
(\%)\end{array}$} & \multirow{2}{*}{$\begin{array}{l}\text { Color } \\
\text { shade } \\
\text { (rating } \\
\text { ) }\end{array}$} \\
\hline & Warp & Weft & & & & & & & & & \\
\hline $\begin{array}{c}0.0 \\
\text { Before } \\
\text { wash } \\
\end{array}$ & $245(0)$ & 136(0) & 0 & $318(0)$ & $4.5(0)$ & 126 & 7.4 & 7.53 & $\begin{array}{c}70 \\
\times 42\end{array}$ & $\begin{array}{c}\mathrm{L}=21 \\
\mathrm{~W}=16\end{array}$ & 5 \\
\hline 20 & $\begin{array}{l}223 \\
(-9 \%)\end{array}$ & $\begin{array}{l}118 \\
(-13 \%)\end{array}$ & $\begin{array}{c}\mathrm{L}=-6.0 \\
W=0\end{array}$ & $\begin{array}{c}330 \\
(+3.8 \% \\
)\end{array}$ & $\begin{array}{l}3.0 \\
(-33 \%)\end{array}$ & 145 & 8.81 & 7.95 & $\begin{array}{c}70 \\
\times 46\end{array}$ & $\begin{aligned} \mathrm{L} & =36 \\
\mathrm{~W} & =20\end{aligned}$ & 4 \\
\hline 30 & $\begin{array}{l}213 \\
(-13 \%)\end{array}$ & $\begin{array}{l}110 \\
(-19 \%)\end{array}$ & $\begin{array}{c}\mathrm{L}=-6.2 \\
W=0\end{array}$ & $\begin{array}{c}334 \\
(+5.0 \% \\
)\end{array}$ & $\begin{array}{l}2.78 \\
(-38 \%)\end{array}$ & 150 & 8.90 & 8.20 & $\begin{array}{c}70 \\
\times 46\end{array}$ & $\begin{aligned} \mathrm{L} & =37 \\
\mathrm{~W} & =22\end{aligned}$ & 4 \\
\hline 40 & $\begin{array}{l}205 \\
(-16 \%)\end{array}$ & $\begin{array}{l}106 \\
(-22 \%)\end{array}$ & $\begin{array}{c}\mathrm{L}=-6.4 \\
\mathrm{~W}=+0.5\end{array}$ & $\begin{array}{c}334 \\
(+5.0 \% \\
)\end{array}$ & $\begin{array}{l}2.60 \\
(-42 \%)\end{array}$ & 155 & 8.92 & 8.60 & $\begin{array}{c}69 \\
\times 46\end{array}$ & $\begin{aligned} \mathrm{L} & =37 \\
\mathrm{~W} & =22\end{aligned}$ & $3 / 4$ \\
\hline 45 & $\begin{array}{l}201 \\
(-18 \%)\end{array}$ & $\begin{array}{l}101 \\
(-26 \%)\end{array}$ & $\begin{array}{c}\mathrm{L}=-6.4 \\
W=+0.5\end{array}$ & $\begin{array}{c}335 \\
+5.3 \% \\
)\end{array}$ & $\begin{array}{l}2.60 \\
(-42 \%)\end{array}$ & 156 & 8.93 & 8.60 & $\begin{array}{c}69 \\
\times 46\end{array}$ & $\begin{aligned} \mathrm{L} & =34 \\
\mathrm{~W} & =20\end{aligned}$ & $3 / 4$ \\
\hline 50 & $\begin{array}{l}195 \\
(-20 \%)\end{array}$ & $\begin{array}{l}98 \\
(-28 \%)\end{array}$ & $\begin{array}{c}L=-6.3 \\
W=+1.0\end{array}$ & $\begin{array}{c}336 \\
+5.6 \% \\
)\end{array}$ & $\begin{array}{l}2.52 \\
(-44 \%)\end{array}$ & 156 & 8.95 & 8.60 & $\begin{array}{c}69 \\
\times 46\end{array}$ & $\begin{array}{c}\mathrm{L}=34 \\
\mathrm{~W}=24\end{array}$ & $3 / 4$ \\
\hline 55 & $\begin{array}{l}190 \\
(-22 \%)\end{array}$ & $\begin{array}{l}95 \\
(-30 \%)\end{array}$ & $\begin{array}{l}\mathrm{L}=-7.2 \\
\mathrm{~W}=+1.0\end{array}$ & $\begin{array}{c}333 \\
+4.7 \% \\
)\end{array}$ & $\begin{array}{l}2.47 \\
(-45 \%)\end{array}$ & 158 & 8.93 & 8.60 & $\begin{array}{c}69 \\
\times 46\end{array}$ & $\begin{aligned} \mathrm{L} & =33 \\
\mathrm{~W} & =24\end{aligned}$ & 3 \\
\hline 60 & $\begin{array}{l}190 \\
(-22 \%)\end{array}$ & $\begin{array}{l}95 \\
(-30 \%)\end{array}$ & $\begin{array}{c}\mathrm{L}=-7.2 \\
\mathrm{~W}=+1.0\end{array}$ & $\begin{array}{c}332 \\
(+4.4 \% \\
)\end{array}$ & $\begin{array}{l}2.47 \\
(-45 \%)\end{array}$ & 158 & 8.95 & 8.60 & $\begin{array}{c}69 \\
\times 46\end{array}$ & $\begin{aligned} \mathrm{L} & =33 \\
\mathrm{~W} & =24\end{aligned}$ & 3 \\
\hline
\end{tabular}

Values at 0.0 concentrations represent the denim garments without cellulase enzyme treatment. Conditions used : enzyme, $2 \%$; acetic acid, $1 \mathrm{~g} / \mathrm{l}$; temp, $55^{\circ} \mathrm{C}$; time, $20-60 \mathrm{~min}$; $\mathrm{pH}, 5.5$; M: L ratio, 1:30.

Table 1 shows that, $0.5 \%$ enzyme concentration causes significant increased the GSM (fabric weight) of the garments. During weaving cotton fabrics were subjected to considerable tensions. In subsequent finishing processes such as calendaring this stretch was increased and temporarily set in the fabric. The fabric is then in a state of dimensional instability ${ }^{9}$. This effect is usually greater in the warp direction. This is known as relaxation shrinkage. Due to relaxation shrinkage fabric GSM is increased.

Thus, $2 \%$ cellulase wash is optimal and this exhibited $42 \%$ decrease in fabric stiffness and maximum shrinkage; and $155 \%$ increase in water absorption, maximum elongation at break and GSM as compared with the other concentrations.

\subsection{Temperature of Cellulase Enzyme Treatment}

The effect of cellulase in denim garment washing under the influence of $40,45,50,55,60$ and $70^{\circ} \mathrm{C}$ for $40 \mathrm{~min}$ was investigated. The effect of temperature on loss in tensile strength, stiffness, color fading, fabric weight, elongation at break, water absorption, moisture regain, moisture content and shrinkage is shown in Table 2 .
Temperatures of washing treatment specifically between 55 and $65^{\circ} \mathrm{C}$ decrease the color shade remarkable; higher temperature, i.e. $70^{\circ} \mathrm{C}$ does not cause further decrease in color shade, because the action of enzyme decreased at higher temperature.

The effect of temperature on stiffness and water absorption is clear particularly when washing was performed at 50,55 and $60^{\circ} \mathrm{C}$, because the looseness of surface fibers by washing temperature. The loss of GSM exhibit values which were at 65 and $70^{\circ} \mathrm{C}$ but substantially GSM values obtained higher at $55^{\circ} \mathrm{C}$. The effect of temperature on surface roughness is clear particularly when enzyme wash was performed at $55^{\circ} \mathrm{C}$.

\subsection{Time of Cellulase Enzyme Treatment}

The effect of time on denim fabric properties is shown in Table 3. The comparison indicates that there are marginal differences in moisture content, moisture regain, EPI (ends/inch) and PPI (picks/inch). But it affects on fabric strength, color fading, softness, shrinkage and GSM. So considering strength, softness, shrinkage, it is selected that 40 min washing time is optimum for denim washing with cellulase enzyme. 


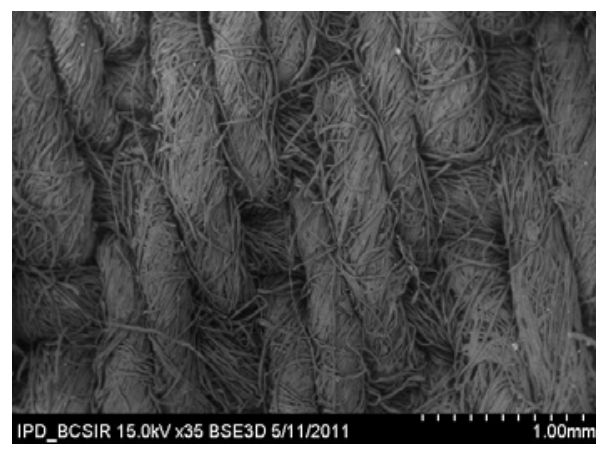

Fig.1a. SEM image of untreated denim

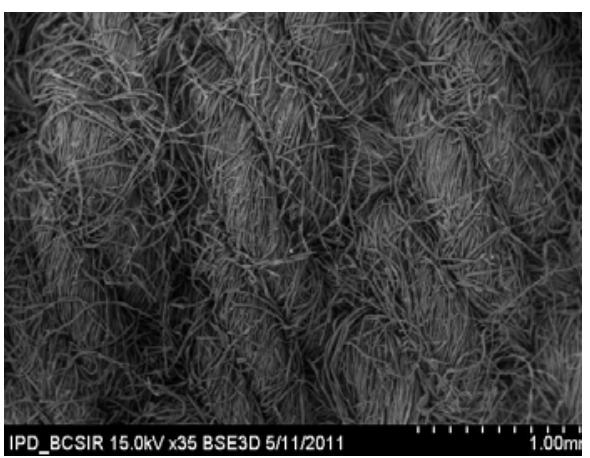

Fig. 2a SEM image of treated denim

\subsection{Scanning Electron Micrograph}

The morphological value of the cotton denim garments were examined by scanning electron microscopy (SEM). Fig. 1 shows SEM images of untreated denim garment. The fig. shows parallel ridges and no ruptures were visible in the images, because yarns are coated with sizing materials. Fig. 2 shows SEM images of enzyme treated denim garment. The fig. shows loosened, disoriented, wrinkled and more cracks on the surface of fibers. This is formed with cellulase washing on cotton denim garments to enzymatic attack.

\section{Conclusions}

The tensile strength, stiffness and color shade decrease after cellulase enzyme washing treatment; meanwhile fabric GSM obtained little bit higher than those of prewashing due to more shrinkage in warp direction. Examination of the enzyme treated fabrics by SEM shows more crack on the fiber surface. It is further noted that pre-washed denim samples are almost stiff and harder than the enzyme treated cotton denim garments.

\section{References}

1. Kashem, M. A. (2008), Garments Merchandising, 1st edn., Lucky-One Traders, Dhaka, Bangladesh, Pp. 69-71.

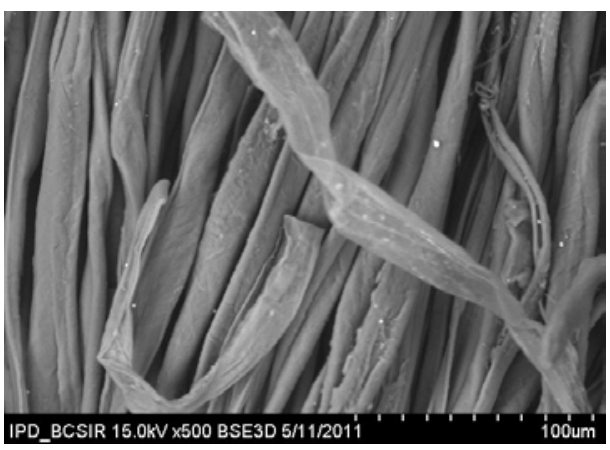

Fig.1b SEM image of untreated denim (magnified)

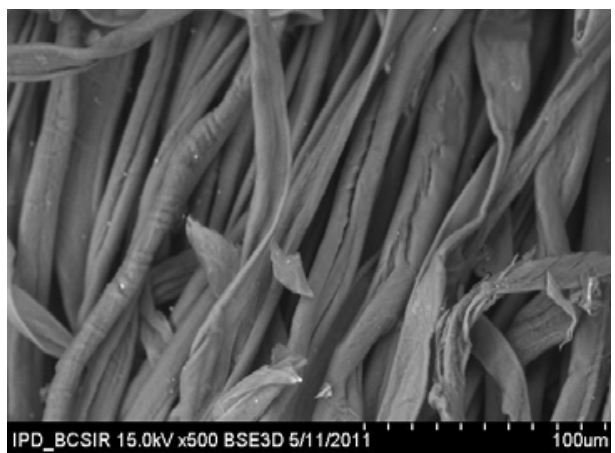

Fig.2b. SEM image of treated denim (magnified)

2. Grieve, M., Biermann, T. and Schaub, K.(2006), The use of indigo derivatives to dye denim material, Science \& Justice, 46:15-24.

3. Islam, M. T. (2010), Garments Washing \& Dyeing, Ananto Publications, Dhaka, , Pp. 220222.

4. Buchert, J. and Heikinheimo, L. (1998), New cellulase processes for the textile industry, Carbohydr. Eur. 22: 2-4.

5. Duran, N. and Marcela, D., (2000), Enzyme applications in the textile industry, Review Progress in Coloration, 30 (1): 41-44.

6. Heikinheimo, L., Buchert, J. and Suominen, P. (2000), Treating denim fabrics with trichoderma reesei cellulases, Textile Res. J. 70 (11):969-973.

7. Morries, C. E. and Harper, R. J. (1994), Comprehensive view on garment dyeing and finishing, American Dyestuff Reporter, 83: 132136.

8. Hams Group, personal communication. (2009), Hams Washing \& Dyeing Limited, 190 Tejgaon I/A, Dhaka, Bangladesh.

9. Cookson, P. G. (1992), Relationships between hygral expansion, relaxation shrinkage, and extensibility in woven wool fabrics, Textile Res. $J$. 62: 44 . 